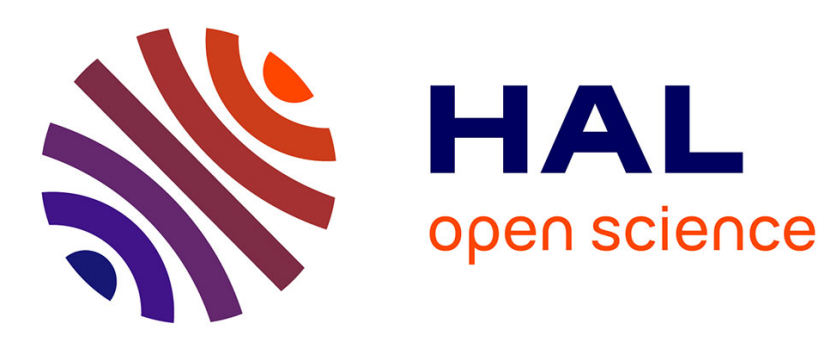

\title{
Stability Investigation of Se- and Te-Substituted Tetrahedrite
}

\author{
Hailong Yang, Marie-Christine Record, Ziya Aliev, Pascal Boulet
}

\section{To cite this version:}

Hailong Yang, Marie-Christine Record, Ziya Aliev, Pascal Boulet. Stability Investigation of Seand Te-Substituted Tetrahedrite. Journal of Electronic Materials, 2020, 49 (6), pp.3566-3576. 10.1007/s11664-020-08043-8 . hal-02507691

\section{HAL Id: hal-02507691 \\ https://hal.science/hal-02507691}

Submitted on 10 Feb 2022

HAL is a multi-disciplinary open access archive for the deposit and dissemination of scientific research documents, whether they are published or not. The documents may come from teaching and research institutions in France or abroad, or from public or private research centers.
L'archive ouverte pluridisciplinaire HAL, est destinée au dépôt et à la diffusion de documents scientifiques de niveau recherche, publiés ou non, émanant des établissements d'enseignement et de recherche français ou étrangers, des laboratoires publics ou privés. 


\section{Stability investigation of Se- and Te-substituted tetrahedrite}

2 Hailong Yang ${ }^{1,2}$, Marie-Christine Record ${ }^{2} *$, Ziya Aliev $^{3}$, Pascal Boulet ${ }^{1}$

$3 \quad{ }^{1}$ Aix-Marseille Univ., CNRS, MADIREL, Marseille, France

$4 \quad{ }^{2}$ Aix-Marseille Univ., CNRS, IM2NP, Marseille, France

$5 \quad{ }^{3}$ Azerbaijan State Oil and Industry University, AZ1010 Baku, Azerbaijan

$6 *$ corresponding author : m-c.record@univ-amu.fr

7

8 DFT (density functional theory) and QTAIM (quantum theory of atoms in molecules)

9 calculations have been performed to investigate the influence of Se and Te substitutions on

10 the stability of tetrahedrite. The formation energies, the laplacian of the electron density, the

11 total and local volume changes and the site charges ones have been determined. The DFT

12 results show that the single atom substitution is the most preferred one and that selenium is

13 preferred for sulphur replacement whereas antimony can be equally replaced by selenium and

14 tellurium. However as selenium substitutes for either sulphur or antimony, QTAIM

15 calculations evidenced large structural and chemical changes in the strutures. Additional

16 experimental results, in agreement with QTAIM ones, allow us to conclude that the

17 investigation of alloys stability can not be limited to DFT calculations of formation energies

18 and total volume changes. QTAIM appears as a valuable complementary method to get

19 information on phase stabilities.

20 Key words: Cu-Sb-S system; substituted tetrahedrite; phase stability; DFT; QTAIM 


\section{INTRODUCTION}

Copper antimony chalcogenides have high potentialities as semiconductors for electrooptic devices, thermoelectric devices, optical recording media and sustainable solar cell. As examples we can mention $\mathrm{Cu}_{3} \mathrm{SbSe}_{3}$ which has enormously drawn attention of the researchers in the thermoelectric field because of its ultra-low lattice thermal conductivity, and the $\mathrm{Cu}-\mathrm{Sb}$ $\mathrm{S}$ compounds that are modern state-of-the-art thermoelectric materials for midtemperature heat-to-power conversion with the advantage of being environmental friendly. The thermoelectric figure of merit $\mathrm{zT}$ for many doped and natural tetrahedrite materials $\left(\mathrm{Cu}_{12} \mathrm{Sb}_{4} \mathrm{~S}_{13}\right)$ gets close to unity at $450^{\circ} \mathrm{C}$; this value is comparable to that of conventional $\mathrm{p}$ type TE materials. However because of the complexity of the $\mathrm{Cu}-\mathrm{Sb}-\mathrm{S}$ phase diagram around the $\mathrm{Cu}_{12} \mathrm{Sb}_{4} \mathrm{~S}_{13}$ composition, these materials are always constituted of several phases for which the proportions generally differ from a sample to another one. The large scale use of tetrahedrite for thermoelectric applications necessitates the mastering of the properties and thus the mastering of the material constitution. A way could be to extend the composition range of the tetrahedrite stability. To reach this goal, we investigated the stability of various substituted tetrahedrites in which $\mathrm{S}$ atoms were replaced by Se and/or Te ones. This work was mainly carried out by coupled DFT and QTAIM calculations and complemented by some experiments.

\section{THE CU-Sb-S SYSTEM}

Information on the constitutive binary systems $\mathrm{Sb}-\mathrm{S}, \mathrm{Cu}-\mathrm{S}$ and $\mathrm{Cu}-\mathrm{Sb}$ can be found in Ref. 1-6, Ref. 7-8 and Ref. 9-11, respectively. The Sb-S phase diagram only shows one condensed stable binary phase $\mathrm{Sb}_{2} \mathrm{~S}_{3}$ (stibnite) with a congruent melting and two regions of liquid immiscibility. The $\mathrm{Cu}-\mathrm{S}$ binary system contains three intermediate phases, namely $\mathrm{Cu}_{2} \mathrm{~S}$ (chalcocite), $\mathrm{Cu}_{9} \mathrm{~S}_{5}$ (digenite) and $\mathrm{CuS}$ (covellite) and a solid solution between digenite 
and chalcocite extending from 83 to $1129^{\circ} \mathrm{C}$. Numerous phases have also been identified at low temperatures $\left(<103^{\circ} \mathrm{C}\right)$ but considerable uncertainties still remain both on the stability range of the digenite and on the temperatures of phase transitions in the low temperature range. Moreover no studies on the stability of the new minerals as roxbyite $\left(\mathrm{Cu}_{1.78} \mathrm{~S}\right)$, geerite

$51\left(\mathrm{Cu}_{1.6} \mathrm{~S}\right)$ and spionkopite $\left(\mathrm{Cu}_{1.4} \mathrm{~S}\right)$ have been performed. There are several intermediate phases in the $\mathrm{Cu}$-rich region but only two $(\delta$ and $\eta)$ exist at room temperature.

Phase stability and phase relations in the $\mathrm{Cu}-\mathrm{Sb}$-S ternary system have been studied by numerous authors. ${ }^{3,12-19}$ There are four compounds in the $\mathrm{Cu}-\mathrm{Sb}-\mathrm{S}$ ternary system, namely $\mathrm{CuSbS}_{2}$ (chalcostibite), $\mathrm{Cu}_{3} \mathrm{SbS}_{3}$ (skinnerite), $\mathrm{Cu}_{3} \mathrm{SbS}_{4}$ (famatinite), and $\mathrm{Cu}_{12} \mathrm{Sb}_{4} \mathrm{~S}_{13}$ (tetrahedrite). Chalcostibite, $\mathrm{CuSbS}_{2}$, forms readily by reaction from the elements and did not show any composition range. ${ }^{3}$ By contrast, Golovei et al. ${ }^{20}$ found a homogeneity range for $\mathrm{CuSbS}_{2}$ and a polymorphic transformation. Skinnerite was first reported by Godolikov et al. ${ }^{17}$ who prepared it by sintering $\mathrm{Cu}_{2} \mathrm{~S}$ and $\mathrm{Sb}_{2} \mathrm{~S}_{3}$ at $480^{\circ} \mathrm{C}$ and $530^{\circ} \mathrm{C}$. It has the ideal composition of $\mathrm{Cu}_{3} \mathrm{SbS}_{3}$ with a small composition field along the line $\mathrm{Cu}_{2} \mathrm{~S}-\mathrm{Sb}_{2} \mathrm{~S}_{3}$ at $500^{\circ} \mathrm{C}$. Karup-Møller et al. ${ }^{21}$ have found these ore aggregates crystallized at about $400^{\circ} \mathrm{C}$ from metal-rich residual magmatic fluids markedly deficient in sulfur. $\mathrm{Cu}_{3} \mathrm{SbS}_{3}$ is stable in the $\mathrm{Cu}-\mathrm{Sb}-\mathrm{S}$ system in the temperature range $359-607^{\circ} \mathrm{C}$. Below $359^{\circ} \mathrm{C}$ this phase decomposes into a mixture of native antimony, chalcostibite and tetrahedrite, ${ }^{3}$ but if it is cooled slowly, it decomposes to give a mixture of tetrahedrite, antimony and digenite. ${ }^{22}$ At $607^{\circ} \mathrm{C}, \mathrm{Cu}_{3} \mathrm{SbS}_{3}$ congruently melts.

66 Pfitzner ${ }^{23}$ have investigated both the high and low-temperature phases. The high-temperature modification is disordered and stable above $122^{\circ} \mathrm{C}$, and is supposed to show high copper ion conductivity or at least a high copper diffusion coefficient. The low-temperature form is ordered and stable below $-9^{\circ} \mathrm{C}$. Famatinite, $\mathrm{Cu}_{3} \mathrm{SbS}_{4}$, derived from sphalerite, melts congruently at $627^{\circ} \mathrm{C}$, and is not known to have any stable polymorph forms. ${ }^{3}$ The only

71 compound with an extensive composition field in the $\mathrm{Cu}-\mathrm{Sb}-\mathrm{S}$ system is tetrahedrite. The 
72 basic structure of minerals of the tetrahedrite group was solved by Pauling and Newman ${ }^{24}$ and 73 now the widely accepted formula $\mathrm{Cu}_{12} \mathrm{Sb}_{4} \mathrm{~S}_{13}$ represented its composition. As for the Pauling 74 and Neuman formula, $\mathrm{Cu}_{12+\mathrm{x}} \mathrm{Sb}_{4+\mathrm{y}} \mathrm{S}_{13}$, where $0 \leq \mathrm{x} \leq 1.92$ and $-0.02 \leq \mathrm{y} \leq 0.27$, there is no clear 75 evidence so far proving the substitution schemes implied in this formula are correct. ${ }^{24}$ Cambi 76 and Elli ${ }^{14}$ have given an extreme composition range for tetrahedrites going from $4 \mathrm{Cu}_{2} \mathrm{~S} \cdot \mathrm{Sb}_{2} \mathrm{~S}_{3}$ 77 to $3 \mathrm{Cu}_{2} \mathrm{~S} \cdot \mathrm{Sb}_{2} \mathrm{~S}_{3}$ (i.e. $\mathrm{Cu}_{8} \mathrm{Sb}_{2} \mathrm{~S}_{7}$ to $\mathrm{Cu}_{3} \mathrm{SbS}_{3}$ ). Since Skinner et al. ${ }^{3}$ have not managed to prepare a single homogenous phase with the composition $\mathrm{Cu}_{12} \mathrm{Sb}_{4} \mathrm{~S}_{13}$, they believed that this phase has a stability temperature range below $300^{\circ} \mathrm{C}$. These authors also found that the unit cell edges of tetrahedrite decrease with the sulfur content. Tatsuka and Morimoto ${ }^{25}$ reported the 81 formation of pseudo-tetrahedrite $\left(\mathrm{T}_{3}{ }_{3}\right)$ which is stable between 250 and $350^{\circ} \mathrm{C}$ and is a 82 superlattice of $\mathrm{Cu}_{12+\mathrm{x}} \mathrm{Sb}_{4+\mathrm{y}} \mathrm{S}_{13}\left(\mathrm{~T}_{3}\right)$ (lattice parameter of $\mathrm{T}_{3}{ }_{3}$ is twice that of $\mathrm{T}_{3}$ ). Along the $83 \mathrm{Cu}_{2} \mathrm{~S}_{-} \mathrm{Sb}_{2} \mathrm{~S}_{3}$ section reported by Chang et al., ${ }^{26}$ the composition of pseudo-tetrahedrite ranges 84 from $\mathrm{Cu}_{3} \mathrm{SbS}_{3}$ to $\mathrm{Cu}_{12.39} \mathrm{Sb}_{4.54} \mathrm{~S}_{13}$. Below $250^{\circ} \mathrm{C}$, a prolonged annealing of $\mathrm{T}_{3}$ or $\mathrm{T}_{3}{ }_{3}$ results in 85 a phase mixture consisting of $\mathrm{Cu}_{3} \mathrm{SbS}_{4}, \mathrm{Cu}_{2-\mathrm{x}} \mathrm{S}$ and $\mathrm{Sb}$. Makowicky and Skinner ${ }^{27}$ have 86 confirmed that tetrahedrite has two room-temperature phases $\mathrm{Cu}$-poor phase $\mathrm{Cu}_{12.3} \mathrm{Sb}_{4} \mathrm{~S}_{13}$ and $87 \mathrm{Cu}$-rich phase $\mathrm{Cu}_{13.8} \mathrm{Sb}_{4} \mathrm{~S}_{13}$ produced by a low-temperature exsolution of tetrahedrite $88 \mathrm{Cu}_{12.59} \mathrm{Sb}_{4.03} \mathrm{~S}_{13}$. However when melts, whose compositions lie near that of tetrahedrite, are cooled at the rate of $50-100^{\circ} \mathrm{C} / \mathrm{h}$, instead of separation of the phase $\mathrm{Cu}_{3} \mathrm{SbS}_{3}$, metastable solid tetrahedrite solutions crystallize out and then decompose to phases with a complex structure, 91 which are absent in the phase diagram. ${ }^{28}$ The crystal structure of stoichiometric tetrahedrite $92 \mathrm{Cu}_{12} \mathrm{Sb}_{4} \mathrm{~S}_{13}$ was determined for the first time by Skinner et al. ${ }^{3}$ There is no phase transitions for $\mathrm{Cu}_{12} \mathrm{Sb}_{4} \mathrm{~S}_{13}$ up to $300^{\circ} \mathrm{C}$, and the two exsolution phases $\mathrm{Cu}_{12.3} \mathrm{Sb}_{4} \mathrm{~S}_{13}$ and $\mathrm{Cu}_{13.8} \mathrm{Sb}_{4} \mathrm{~S}_{13}$ 94 show a high copper-ion mobility even at room temperature. According to [29] tetrahedrite is 95 stable from $4 \mathrm{Cu}_{2} \mathrm{~S} \cdot \mathrm{Sb}_{2} \mathrm{~S}_{3}$ to $\mathrm{Cu}_{3} \mathrm{SbS}_{3}$ at $300^{\circ} \mathrm{C}$ and from $4 \mathrm{Cu}_{2} \mathrm{~S} \cdot \mathrm{Sb}_{2} \mathrm{~S}_{3}$ to $\mathrm{Cu}_{12} \mathrm{Sb}_{4} \mathrm{~S}_{13}$ at $400^{\circ} \mathrm{C}$. 96 Whereas Skinner et al. ${ }^{3}$ reported above $500^{\circ} \mathrm{C}$ a rapid shrinkage of the composition range for 
tetrahedrite followed by its decomposition into $\mathrm{Cu}_{3} \mathrm{Sb}_{1} \mathrm{~S}_{4}, \mathrm{Cu}_{3} \mathrm{SbS}_{3}$ and $\mathrm{Cu}_{\mathrm{x}} \mathrm{S}$ (x going from

All the ternary phases are stable at $500^{\circ} \mathrm{C}$.

101 phases are given in Table 1 and Table 2, respectively.

Table I. Crystallographic data of the Cu-Sb-S ternary solid phases

\begin{tabular}{lllll}
\hline Phase / Name & Crystal & Space & Lattice parameters (pm) & Reference \\
& system & group & & \\
& & & & \\
\hline $\mathrm{Cu}_{3} \mathrm{SbS}_{4}$ & Tetragonal & $\mathrm{I}-42 \mathrm{~m}$ & $\mathrm{a}=538.5, \mathrm{c}=1075.4$ & {$[30]$}
\end{tabular}

/Famatinite

$\mathrm{CuSbS}_{2}$

Orthorhombic Pnma

$\mathrm{a}=601.8, \mathrm{~b}=379.58, \mathrm{c}=1449.5$

/Chalcostibite

$\mathrm{Cu}_{12} \mathrm{Sb}_{4} \mathrm{~S}_{13} \quad$ Cubic $\quad \mathrm{I}-43 \mathrm{~m} \quad \mathrm{a}=1032.4$

/Tetrahedrite

$\mathrm{Cu}_{3} \mathrm{SbS}_{3} \quad$ Monoclinic $\quad \mathrm{P} 2{ }_{1} / \mathrm{c} \quad \mathrm{a}=781.5, \mathrm{~b}=1025.2, \mathrm{c}=1327.0$

/Skinnerite

Table II. Thermodynamic properties of the $\mathrm{Cu}$-Sb-S ternary solid phases from Ref. 34

\begin{tabular}{ccccc}
\hline Phase & Temperature & $\Delta_{\mathrm{f}} \mathrm{G}^{0}$ & $\Delta_{\mathrm{f}} \mathrm{H}^{0}$ & $\mathrm{~S}^{0}$ \\
& & $(\mathrm{~J} / \mathrm{mol}$ of atoms $)$ & $(\mathrm{J} / \mathrm{mol}$ of atoms $)$ & $(\mathrm{J} / \mathrm{K} . \mathrm{mol}$ of atoms $)$ \\
\hline $\mathrm{Cu}_{3} \mathrm{SbS}_{4}$ & $25^{\circ} \mathrm{C}$ & $-207500 \pm 3900$ & $-200000 \pm 6300$ & $298 \pm 18$ \\
$\mathrm{CuSbS}_{2}$ & $25^{\circ} \mathrm{C}$ & $-121400 \pm 3400$ & $-119000 \pm 3500$ & $148 \pm 6.4$ \\
$\mathrm{Cu}_{3} \mathrm{SbS}_{3}$ & $25^{\circ} \mathrm{C}$ & $-197800 \pm 3800$ & $-189300 \pm 6500$ & $269.5 \pm 13.7$ \\
\hline
\end{tabular}




\section{Computational details}

The calculations have been performed in the frame of the density-functional theory ${ }^{35,36}$

using the gradient-corrected Perdew-Burke-Ernzerhof (PBE) exchange-correlation

109 functionals. ${ }^{37}$ All the structures have been relaxed to their equilibrium state and the energy and force thresholds have been fixed to $10^{-7} \mathrm{Ry}$ and $10^{-4} \mathrm{Ry} \cdot \mathrm{bohr}^{-1}$, respectively. The projector augmented wave (PAW) method ${ }^{38}$ has been used to treat nucleus and core and valence

112 electrons interactions with cutoffs 48 Ry for the energy and 480 Ry for the density. A 4x4x4 113 k-point mesh has been utilized. The Quantum Espresso program package has been used for 114 these calculations. ${ }^{39}$

115 The analysis of the bonding structure of the alloys has been performed using Bader's quantum theory of atoms in molecule $\mathrm{e}^{40}$ as implemented in the Critic2 program. ${ }^{41}$

\section{Crystalline description of the tetrahedrite}

The tetrahedrite crystal structure with stoichiometric formula $\mathrm{Cu}_{12} \mathrm{Sb}_{4} \mathrm{~S}_{13}$ is composed

120 of two formula units and belongs to the body-centered cubic Bravais lattice with group number 217 (I-43m). It contains 29 atoms in the irreducible lattice located at five crystallographic sites. Copper atoms are in the two distinct Wyckoff positions (WP) 12e and

$12312 \mathrm{~d} . \mathrm{Cu} 12 \mathrm{e}$ is at the centre of a triangle formed by three sulphur atoms (two $\mathrm{S}$ in $24 \mathrm{~g}$ WP and 124 one $\mathrm{S}$ in 2a WP) and the assembly constitutes a trigonal plane. If one includes two antimony 125 atoms on either sides of the plane the assembly is a trigonal bipyramid (Fig. 1a). It is noted 126 that the $\mathrm{Cu}-\mathrm{Sb}$ bond distance of this trigonal bipyramid is rather large with $3.536 \AA$ and the $127 \mathrm{Cu}-\mathrm{S}$ ones amount to $2.246 \AA$ and $2.250 \AA$. It has been reported that, the weak bonding 128 between $\mathrm{Cu}$ and $\mathrm{Sb}$ leads to soft vibrational modes of $\mathrm{Cu}$ having large anisotropic thermal 129 motion, which could explain the low thermal conductivity of the tetrahedrite. ${ }^{32,42} \mathrm{Six} \mathrm{Cu}$ 
130 atoms in 12e WP are located nearby the centre of the lattice forming an octahedron around a

131 sulphur atom in 2a Wyckoff position (Fig. 1b). The additional six $\mathrm{Cu} 12 \mathrm{e}$ atoms are located at

132 the cube edges nearby the lattice corners occupied by S 2 a atoms. Copper atoms in $12 \mathrm{~d}$ WP

133 form a tetrahedral arrangement with four sulphur atoms in $24 \mathrm{~g}$ WP. They are located on the

134 cube faces and form a square assembly with three other $\mathrm{Cu}$ atoms in $12 \mathrm{~d}$ WP (Fig. 1c). The

135 corresponding $\mathrm{Cu}-\mathrm{Cu}$ distance is as large as 3.650 $\AA$. The $\mathrm{Cu}-\mathrm{S}$ distances are $2.311 \AA$ and the

$136 \mathrm{~S}-\mathrm{Cu}-\mathrm{S}$ angles amount to $111.5^{\circ}$. As just mentioned the sulphur atoms in the $2 \mathrm{a}$ WP are

137 located both at the corner and at the centre of the cubic lattice, and are at the centre of a

138 regular octahedron formed with the $\mathrm{Cu}$ atoms in 12e WP (Fig. 1b). The $\mathrm{Cu}-\mathrm{S}$ bond distances

139 are $2.250 \AA$. Sulphur atoms occupying the $24 \mathrm{~g}$ WP form a distorted tetrahedron with their

140 neighbours, that are one $\mathrm{Sb}$, two $\mathrm{Cu} 12 \mathrm{~d}$ and one $\mathrm{Cu} 12 \mathrm{e}$ atoms, with bond distances of 2.452

$141 \AA, 2.311 \AA$ and $2.246 \AA$, respectively (Fig. 1d). The antimony atoms are located in sites 8c

142 and are surrounded by three sulphur $24 \mathrm{~g}$ atoms, forming a pyramidal arrangement. As

143 mentioned above the antimony atoms constitute the apex of a trigonal bipyramid for which $\mathrm{Cu}$

144 is the centre. It is noted that the height of the pyramid made of $\mathrm{Sb}$ and three $\mathrm{S}$ atoms is not

145 aligned with that of the trigonal bipyramid but is tilted by $35.3^{\circ}$. The three $\mathrm{Sb}-\mathrm{S}$ bond lengths equal $2.452 \AA$ and the angles are $95.7^{\circ}$.

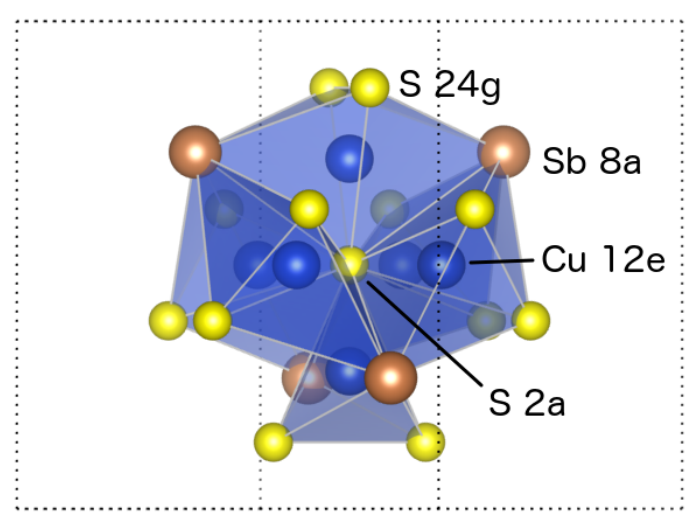

a) Copper $12 e$ at the centre of a trigonal bipyramid with $\mathrm{S} 2 a, \mathrm{~S} 24 \mathrm{~g}$ and $\mathrm{Sb} 8 c$ at the apex.

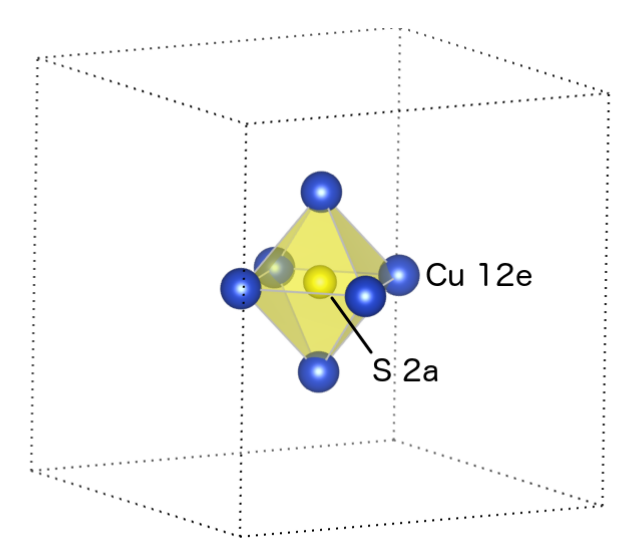

b) Sulphur $2 a$ at the centre of the lattice and at the center of an octahedron formed by six $\mathrm{Cu}$ $12 e$. 


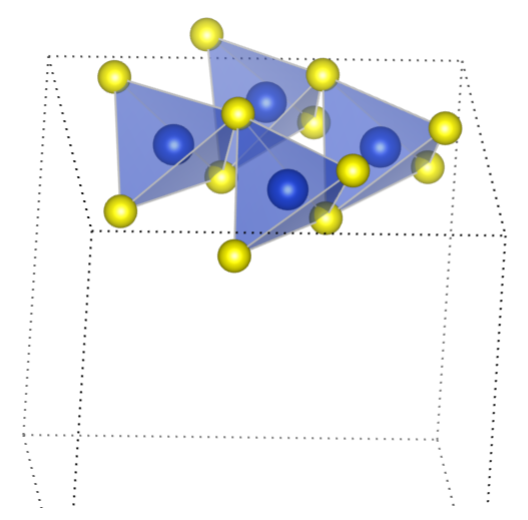

c) Copper $12 d$ arranged in square at the lattice face. They are located at the centre of a tetrahedron with S $24 g$ at the apex.

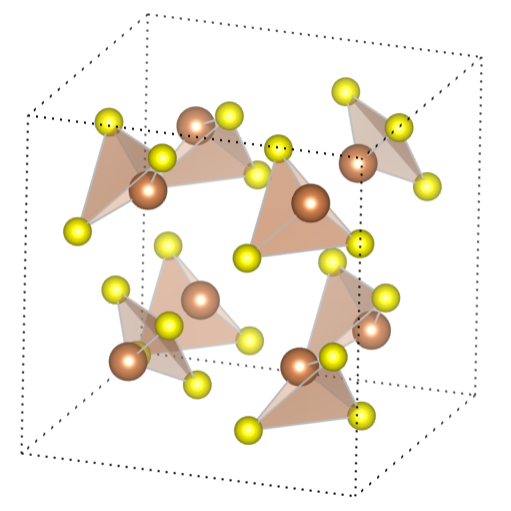

e) Antimony at the apex of a tetrahedron formed with three sulphur $24 \mathrm{~g}$ atoms

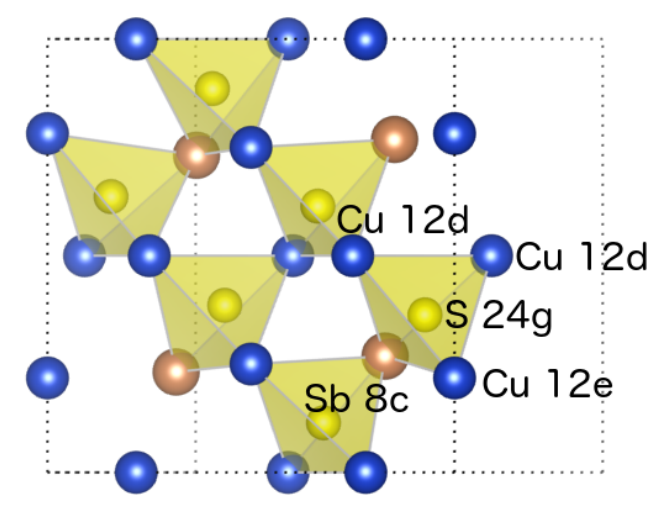

d) Sulphur $24 \mathrm{~g}$ in the centre of a distorted tetrahedron formed by two $\mathrm{Cu} 12 d$ (at the lattice face), one $\mathrm{Cu} 12 e$ (at the lattice edge) and one $\mathrm{Sb}$ $8 c$.

148 Fig. 1: Structural features of the tetrahedrite. a) Environment of copper in $12 e$ Wyckoff 149 position (WP); b) Environment of sulphur in $2 a \mathrm{WP}$; c) Environment of copper in $12 d \mathrm{WP}$; ) 150 Environment of sulphur in $24 g$ WP; e) Environment of antimony in $8 c$ WP.

\section{Procedure}

The substituting elements considered in this work are Se and Te. The substituted 154 atoms have been chosen as $\mathrm{S}$ and $\mathrm{Sb} ; \mathrm{S}$ as a chalcogen and $\mathrm{Sb}$ since its replacement by Te has 155 been evidenced in natural tetrahedrite. ${ }^{43}$ As neither $\mathrm{Cu}_{12} \mathrm{Sb}_{4} \mathrm{Se}_{13}$ nor $\mathrm{Cu}_{12} \mathrm{Sb}_{4} \mathrm{Te}_{13}$ have been 
156 reported in literature, in order to preclude a too big distorsion of the cell only the substitutions

157 by one and two atoms per cell have been examined. The investigated compositions are the following ones : $\mathrm{Cu}_{12} \mathrm{Sb}_{4} \mathrm{~S}_{12.5} \mathrm{Se}_{0.5}, \mathrm{Cu}_{12} \mathrm{Sb}_{4} \mathrm{~S}_{12} \mathrm{Se}_{1}$,

$$
\mathrm{Cu}_{12} \mathrm{Sb}_{3.5} \mathrm{Se}_{0.5} \mathrm{~S}_{13}, \mathrm{Cu}_{12} \mathrm{Sb}_{3} \mathrm{Se}_{1} \mathrm{~S}_{13}, \mathrm{Cu}_{12} \mathrm{Sb}_{4} \mathrm{~S}_{12.5} \mathrm{Te}_{0.5}, \mathrm{Cu}_{12} \mathrm{Sb}_{4} \mathrm{~S}_{12} \mathrm{Te}_{1}, \mathrm{Cu}_{12} \mathrm{Sb}_{3.5} \mathrm{Te}_{0.5} \mathrm{~S}_{13} \text {, }
$$

$160 \mathrm{Cu}_{12} \mathrm{Sb}_{3} \mathrm{Te}_{1} \mathrm{~S}_{13}$. The atom replacements on all the crystallographic sites $(2 \mathrm{a}$ and $24 \mathrm{~g}$ for $\mathrm{S}, 8 \mathrm{c}$

161 for $\mathrm{Sb}$ ) have been envisaged. For $2 \mathrm{Te}$ or Se atoms substitutions in the case of sulphur, three 162 possible situations have been considered: 2 atoms at site S $24 g$, one atom at site S $24 g$ and the

163 other at site S $2 a$, and 2 atoms at site S $2 a$. For 2 Te or Se atoms substitutions in the case of 164 antimony, since in pure tetrahedrite the eight antimony atoms form a somewhat distorted cube 165 (hereafter called pseudo-cube) inside the cubic lattice, three possibilities have been 166 considered: two atoms along the pseudo-cube edge, two atoms along the face diagonal of the 167 pseudo-cube and 2 atoms along the principal diagonal of the pseudo-cube. The stability of the 168 phases have been investigated by determining both the formation energies of the alloys using 169 DFT calculations and the total and local volume changes using QTAIM ones. The formation energies have been determined from the energies E calculated by DFT 171 according to the following formula:

$\Delta E_{f}=\frac{E\left(\mathrm{Cu}_{\mathrm{x}} \mathrm{Sb}_{y} \mathrm{~S}_{\mathrm{z}} \mathrm{X}_{\mathrm{t}}\right)-\mathrm{x} E(\mathrm{Cu})-\mathrm{y} E(\mathrm{Sb})-\mathrm{z} E(\mathrm{~S})-\mathrm{t} E(\mathrm{X})}{\mathrm{x}+\mathrm{y}+\mathrm{z}+\mathrm{t}}$

173 Recalling that the number of formula in the unit cell of tetrahedrite is 2 , a one-atom sulphur 174 and antimony substituted tetrahedrite on the one hand and a two-atoms sulphur and antimony 175 substituted tetrahedrite on the other hand correspond to $\mathrm{Cu}_{12} \mathrm{Sb}_{4} \mathrm{~S}_{12.5} \mathrm{X}_{0.5}, \mathrm{Cu}_{12} \mathrm{Sb}_{3.5} \mathrm{X}_{0.5} \mathrm{~S}_{13}$, and $176 \mathrm{Cu}_{12} \mathrm{Sb}_{4} \mathrm{~S}_{12} \mathrm{X}, \mathrm{Cu}_{12} \mathrm{Sb}_{3} \mathrm{XS}_{13}$, respectively. 


\section{Results}

Formation energies and total lattice volume changes

184 single substitution, both selenium and tellurium atoms prefer occupying site $24 g$, the 185 formation energies being -160.7 and $-151.6 \mathrm{meV} /$ atom respectively. The substitution at site $1862 a$ is much less favourable by about $8 \mathrm{meV} /$ atom. This preference for the $24 g$ site has already 187 been experimentally evidenced for Se by Lu et al. ${ }^{44}$ For two Te or Se atoms substitutions as mentioned above three possible situations have been envisaged: two atoms at site $\mathrm{S} 24 \mathrm{~g}$, one 189 atom at site S $24 g$ and the other at site S $2 a$, and 2 atoms at site S $2 a$. For the two former 190 possibilities we observe that for a given substituting atom the energies are very close and 191 actually lie in the error bar that we estimate to be 3-4 meV/atom. The 2-atoms substitution at 192 site $2 a$ is the least preferential one for both Se and Te. We note that, the substitution with 193 selenium is more preferred than that with tellurium, as the formation reactions pertaining to 194 Se are more exothermic than those pertaining to Te. These results show that whatever the substituting atom (Se or Te), the most favorable 196 situation corresponds to a single atom substitution at site $24 \mathrm{~g}$ and that irrespective of the 197 considered site, the replacement of S by Se is the most favorable one. 
Table III: Formation energies (in meV/atom) and total volume change of the cell (in bohr $^{3}$ ) for 1 and 2 atoms Te or Se substitutions for sulphur. Columns 1 and 8 correspond to the ranking w.r.t. formation energies.

\begin{tabular}{|c|c|c|c|c|c|c|c|}
\hline & Te substituted for $\mathrm{S}$ & $\Delta \mathrm{E}_{\mathrm{f}}$ & $\Delta \mathrm{V}$ & $\Delta \mathrm{E}_{\mathrm{f}}$ & $\Delta \mathrm{V}$ & Se substituted for $\mathrm{S}$ & \\
\hline 1 & $1 \mathrm{Te}$ for $\mathrm{S} 24 \mathrm{~g}$ & -151.6 & +1.297 & -160.7 & +0.093 & $1 \mathrm{Se}$ for $\mathrm{S} 24 \mathrm{~g}$ & 1 \\
\hline 2 & $1 \mathrm{Te}$ for $\mathrm{S} 2 a$ & -144.0 & +2.452 & -153.1 & +0.312 & $1 \mathrm{Se}$ for $\mathrm{S} 2 a$ & 4 \\
\hline 3 & $2 \mathrm{Te}$ for $2 \mathrm{~S} 24 g$ & -136.7 & +3.066 & -155.5 & +0.943 & $2 \mathrm{Se}$ for $2 \mathrm{~S} 24 \mathrm{~g}$ & 2 \\
\hline \multirow[t]{2}{*}{4} & $1 \mathrm{Te}$ for $\mathrm{S} 24 \mathrm{~g}$ and & -136.2 & +3.976 & -153.5 & +0.685 & $1 \mathrm{Se}$ for $\mathrm{S} 24 \mathrm{~g}$ and & 3 \\
\hline & $1 \mathrm{Te}$ for $\mathrm{S} 2 a$ & & & & & $1 \mathrm{Se}$ for $\mathrm{S} 2 a$ & \\
\hline 5 & $2 \mathrm{Te}$ for $2 \mathrm{~S} 2 a$ & -127.3 & +6.200 & -144.7 & +1.828 & $2 \mathrm{Se}$ for $2 \mathrm{~S} 2 a$ & 5 \\
\hline
\end{tabular}

The total volume of the substituted structures changes sizeably with respect to that of

201 pristine tetrahedrite as can be seen in Table 3. We observe that, except for 2-Se-atoms 202 substitution, the more energetically favorable the site is, the smaller the volume change. In 203 agreement with the respective atomic volumes of Se and Te atoms, sites substituted with Te 204 are likely to be more affected, as we observe a larger total volume change, than when Se is the 205 substituting element. It appears that, substitutions on site S $2 a$ induces more drastic changes in 206 the total volume than those on site $\mathrm{S} 24 \mathrm{~g}$, the volume change being about two to three times 207 as large. As a consequence, the volume increase for 2-atoms substitution at site S $2 a$ is as 208 large as +6 and nearly $+2 \mathrm{Bohr}^{3}$ for Te and Se, respectively. These results on the volumes are 209 in line with the energetic ones as they can lead to the same inferences as above. 
Substitutions of Se and Te for Sb. The calculated values are given in Table 4.

212 Remarkably enough, the formation energies are quite similar, suggesting therefore that both

213 Se and Te may equally substitute for $\mathrm{Sb}$. The most preferred substitution is by far obtained

214 with one Se or Te atom only in place of antimony. The energy difference between the one-

215 atom and two-atoms substitutions is above $20 \mathrm{meV} /$ atom for both $\mathrm{Se}$ and Te, the largest

216 energy difference being $23 \mathrm{meV} /$ atom for Se. For two-atoms substitutions, the three

217 configurations, namely two atoms along the pseudo-cube edge, two atoms along the face

218 diagonal of the pseudo-cube and two atoms along the principal diagonal of the pseudo-cube,

219 are energetically undistinguishable since the differences in formation energies lie in the error

220 bar $(3-4 \mathrm{meV} /$ atom $)$; they spread in the ranges $[-122.2 ;-123.8] \mathrm{meV} /$ atom and $[-120.4 ;-$

221 122.5] meV/atom for Te and Se, respectively.

222 Regarding the total volume change of the lattice upon substitutions, it is remarkable

223 that they are all negative irrespective of the substituting atom and configurations. The smallest

224 volume change corresponds to the one-atom substitution. For two-atoms substitutions the

225 situation is contrasted between Se and Te. For Se, the volume changes remain rather small

226 (less than $2 \mathrm{Bohr}^{3}$ ). For Te, the two-atoms substitutions at the edge of the pseudo-cube still

227 lead to the modest volume change of $-2.6 \mathrm{Bohr}^{3}$. By contrast, a huge change is observed

228 when two $\mathrm{Sb}$ atoms are replaced by $\mathrm{Te}$ on the pseudo-cube face and body diagonals.

229 Notwithstanding this observation, the structures are not energetically destabilized as 230 mentioned above. 
Table IV: Formation energies (in meV/atom) and total volume change of the cell (in bohr ${ }^{3}$ ) for 1 and 2 atoms Te or Se substitutions for antimony. Columns 1 and 8 correspond to the ranking w.r.t. formation energies.

\begin{tabular}{|c|c|c|c|c|c|c|c|}
\hline & Te substituted for $\mathrm{Sb}$ & $\Delta \mathrm{E}_{\mathrm{f}}$ & $\Delta \mathrm{V}$ & $\Delta \mathrm{E}_{\mathrm{f}}$ & $\Delta \mathrm{V}$ & Se substituted for $\mathrm{Sb}$ & \\
\hline 1 & $1 \mathrm{Te}$ for $\mathrm{Sb} 8 \mathrm{c}$ & -144.8 & -1.2 & -143.4 & -1.24 & $1 \mathrm{Se}$ for $\mathrm{Sb} 8 \mathrm{c}$ & 1 \\
\hline 2 & $\begin{array}{l}2 \mathrm{Te} \text { for } 2 \mathrm{Sb} 8 c \\
\text { (pseudo-cube edge) }\end{array}$ & -123.8 & -2.6 & -122.5 & -1.91 & $\begin{array}{l}2 \mathrm{Se} \text { for } 2 \mathrm{Sb} 8 c \\
\text { (pseudo-cube edge) }\end{array}$ & 2 \\
\hline 3 & $\begin{array}{l}2 \mathrm{Te} \text { for } 2 \mathrm{Sb} 8 \mathrm{c} \\
\text { (pseudo-cube } \\
\text { diagonal) }\end{array}$ & -123.6 & -26.5 & -120.7 & -1.71 & $\begin{array}{l}2 \mathrm{Se} \text { for } 2 \mathrm{Sb} 8 \mathrm{c} \\
\text { (pseudo-cube } \\
\text { diagonal) }\end{array}$ & 3 \\
\hline 4 & $\begin{array}{l}2 \mathrm{Te} \text { for } 2 \mathrm{Sb} 8 c \\
\text { (pseudo-cube face } \\
\text { diagonal) }\end{array}$ & -122.2 & -36.1 & -120.4 & -1.93 & $\begin{array}{l}2 \mathrm{Se} \text { for } 2 \mathrm{Sb} 8 \mathrm{c} \\
\text { (pseudo-cube face } \\
\text { diagonal) }\end{array}$ & 4 \\
\hline
\end{tabular}

Partial conclusions. From the formation energies viewpoint the most favourable

234 situation corresponds to a single atom substitution, both Te and Se preferring replacing 235 sulphur at the $24 g$ Wyckoff position to sulphur $2 a$ and antimony $8 c$ ones. Selenium is 236 preferred for the sulphur substitution whereas tellurium and selenium are equally likely to replace antimony.

The lattice volume change is positive when substitutions occur at the sulphur sites,

239 whereas it is negative at the antimony ones, the one atom substitution leading in all cases to 240 the lower volume variation. For two-atoms substitutions, irrespective to the substituted 241 element and site, Te leads to higher volume changes than Se. One can note that, whereas these 242 volume variations are extremely large when Te substitutes for $\mathrm{Sb}$, the energetic variations are 243 quite small. 
247 In order to get better insight into the influence of substitutional atoms in the tetrahedrite, the

248 atomic site volume and charge changes and electron density laplacian have been calculated

249 using Bader's theory of atoms in molecules. Only one-atom substitutions are considered here

250 since these lead to the structures bearing highest formation energies and smallest volume 251 changes.

252 Pure tetrahedrite. The electron density laplacian of pure tetrahedrite in the (110) 253 plane is depicted in figure 2. This plane contains S $2 a$ atoms (e.g. sulphur located at abscissa 254 ca. 22), which are bonded to two copper $12 e$ (at abscissa ca. 20 and 24); the four remaining 255 copper $12 e$ atoms that complete the octahedra around sulphur ones are located in two planes 256 rotated by $45^{\circ}$ from the (110) one and are thus not visible.

257 In the (110) plane, one can see that in agreement with the structure description already 258 reported in literature, $\mathrm{Cu} 12 e$ is bonded to two $\mathrm{S} 24 \mathrm{~g}$ atoms and despite the long distance 259 between copper $12 e$ and antimony atoms (3.536 $\AA$, see above), these atoms are chemically 260 bonded to each other since a bond path is found to connect them and a bond critical point 261 (BCP) is found at the atomic basins boundary. Indeed, in the Bader's description the bonds 262 are characterized by a path connecting two atoms, with b (see Fig. 2) depicting the position of 263 the BCP where the electron density gradient vanishes. 


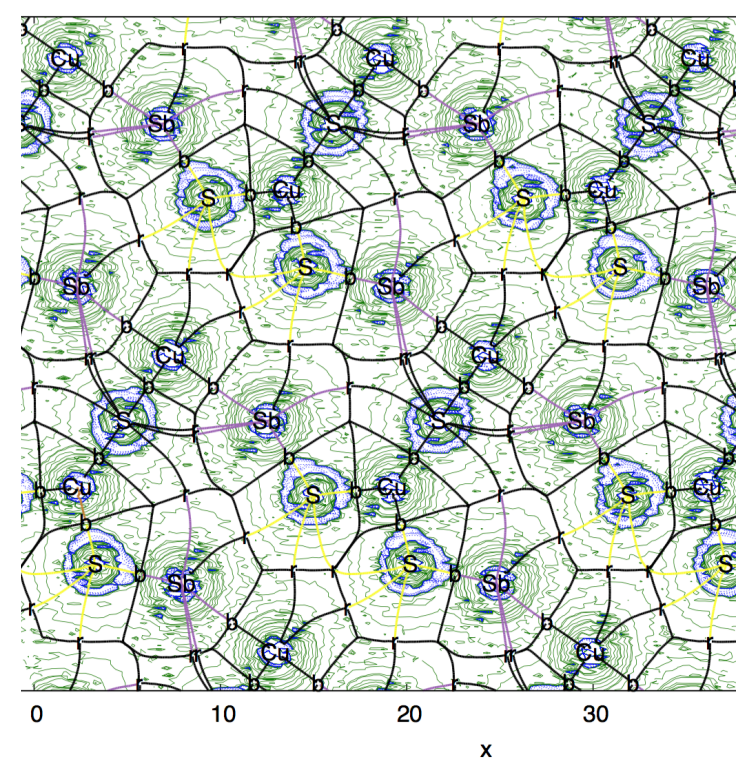

266 Fig. 2: Electron density laplacian of pure tetrahedrite. Legend. b: bond critical point; r: ring

267 critical point; c: cage critical point. Color legend: electron accumulation in blue; electron 268 depletion in green.

269

Substitutions of Se and Te for S $24 \mathrm{~g}$. As one selenium atom replaces a sulphur $24 \mathrm{~g}$

271 atom, one of the $\mathrm{Cu}_{12 \mathrm{e}}-\mathrm{Sb}$ bonds gets broken. This effect is observable as one compares Fig. 2

272 (at $\mathrm{x}=26$ ) and Fig. 3a (at $\mathrm{x}=31$ ). Important distortions in the structure are also observed,

273 probably to accommodate the large size of Se: the $\mathrm{Cu}_{12 \mathrm{e}}-\mathrm{Se}$ bond distance $(2.541 \AA)$ increases

274 by $13 \%$ compared to the $\mathrm{Cu}_{12 \mathrm{e}} \mathrm{S}$ one; $\mathrm{Cu} 12 e$ moves out of the trigonal plane by about $20 \%$;

275 the angle $\mathrm{Cu}_{12 \mathrm{e}}-\mathrm{S}_{2 \mathrm{a}}-\mathrm{Cu}_{12 \mathrm{e}}$ of the octahedron height is $150^{\circ}$ instead of $180^{\circ}$. One of the $\mathrm{Cu}_{12 \mathrm{e}^{-}}$

$276 \mathrm{Sb}$ distances shortens by $20 \%(2.832 \AA)$ while the other enlarges by $10 \%(3.896 \AA)$ that leads

277 to the bond breaking. 


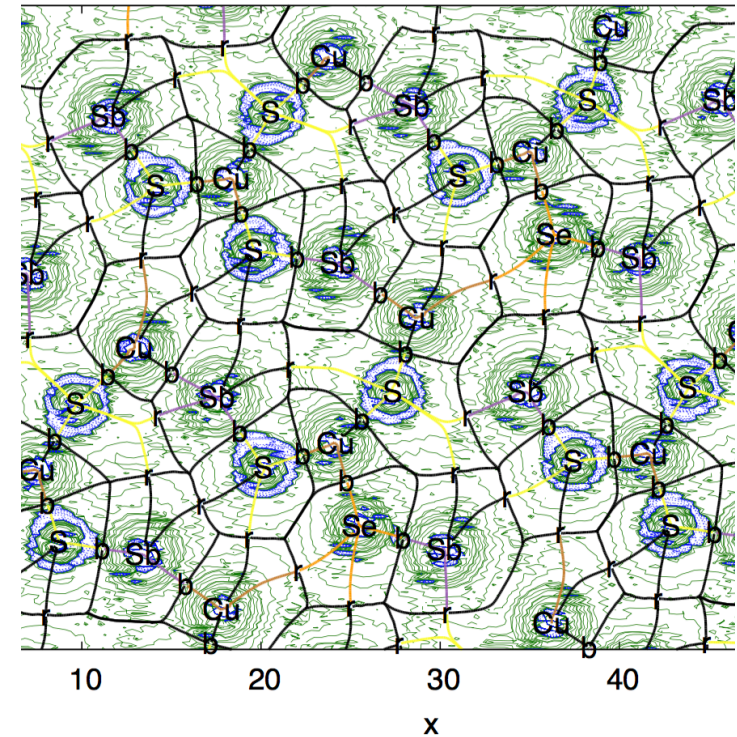

a) Se substitution for $\mathrm{S} 24 \mathrm{~g}$

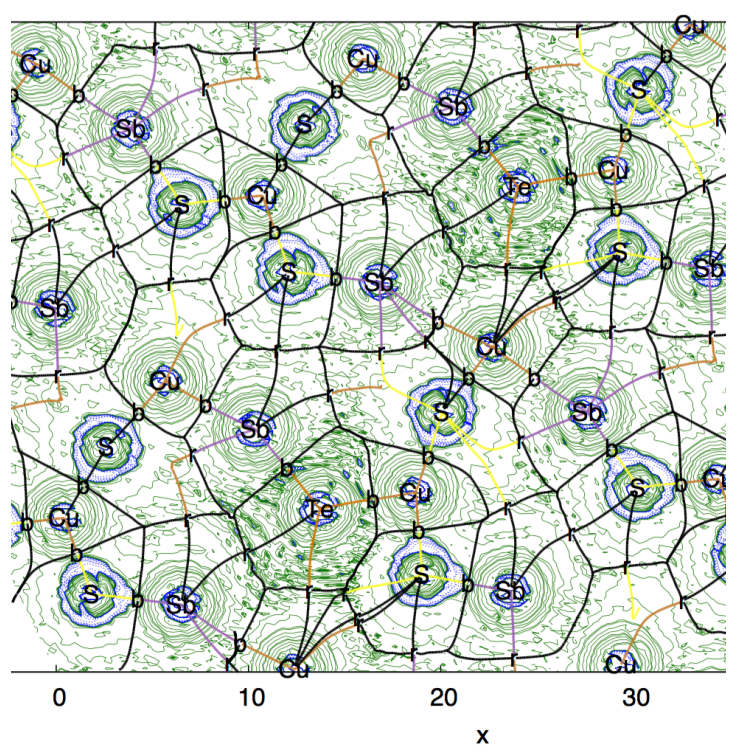

b) Te substitution for S $24 g$

279 Fig. 3: Electron density laplacian of substituted tetrahedrite. a) Se substitution for S 24g; b)

280 Te substitution for S $24 g$. Legend. b: bond critical point; r: ring critical point; c: cage critical

281 point. Color legend: electron accumulation in blue; electron depletion in green.

Table V: Variation of the atomic charge (in electron charge unit) and atomic sites volume (in bohr ${ }^{3}$ ) upon Se substitution for $\mathrm{S} 24 \mathrm{~g}$.

\begin{tabular}{llllll}
\hline & $24 \mathrm{~g}(\mathrm{~S})$ & $2 \mathrm{a}(\mathrm{S})$ & $12 \mathrm{e}(\mathrm{Cu})$ & $12 \mathrm{~d}(\mathrm{Cu})$ & $8 \mathrm{c}(\mathrm{Sb})$ \\
\hline$\Delta \mathrm{q}$ & +0.01 & +0.05 & -0.01 & -0.01 & 0 \\
$\Delta \mathrm{V}$ & +1.15 & +5 & -2.26 & +0.45 & -1.31 \\
\hline
\end{tabular}

The effect of this replacement on the atomic charges and atomic volumes can be seen

285 in Table 5. Interestingly, sulphur $2 a$ is the most affected atom with a positive change of both 286 properties; a volume increase as large as $+5 \mathrm{bohr}^{3}$ is observed. The $\mathrm{Cu} 12 e$ atom to which $\mathrm{Se}$ 287 is bonded is also affected, though in a lower extent and in the opposite way with a decrease of 288 both the volume and the charge. The site of the antimony atom to which Se is bonded 
undergoes a volume decrease although its charge remains unchanged. The volume decrease is

290 about the same in absolute value as the volume increase of the $\mathrm{S} 24 \mathrm{~g}$ site where the 291 substitution occurs.

As Te substitutes for sulphur $24 g$ the same overall trends are observed as for Se. The 293 graph of the electron density laplacian (Fig. 3b) shows that one of the $\mathrm{Cu}_{12 \mathrm{e}}-\mathrm{Sb}$ is broken $294(3.592 \AA,+1.2 \%)$ while the other one is strengthened $(3.181 \AA,-10 \%)$ and the octahedron around $\mathrm{S} 2 a$ is distorted (the $\mathrm{Cu}-\mathrm{S}-\mathrm{Cu}$ angle is $163^{\circ}$ ). However, we note that these structural changes are less drastic than for Se, although the Te substitution is energetically less 297 favorable than the Se one. The volume change of the site $24 g$ of sulphur, where the Te substitution occurs, increases sizably (Table 6) by $+3.3 \mathrm{Bohr}^{3}$ (2.9 times that for $\mathrm{Se}$ substitution) and the volume of the site $12 d(\mathrm{Cu})$ is almost twice as large as that for the Se substitution. Only the site $12 e$ of $\mathrm{Cu}$ undergoes a volume decrease of about the same amount as for Se substitution. These local volume changes explain why the overall volume of the structure increases (Table 3) as Te substitutes for sulphur.

304 for the Se substitution.

305

Table VI: Variation of the atomic charge (in electron charge unit) and atomic sites volume (in bohr $^{3}$ ) upon Te substitution for $S 24 g$

\begin{tabular}{llllll}
\hline & $24 \mathrm{~g}(\mathrm{~S})$ & $2 \mathrm{a}(\mathrm{S})$ & $12 \mathrm{e}(\mathrm{Cu})$ & $12 \mathrm{~d}(\mathrm{Cu})$ & $8 \mathrm{c}(\mathrm{Sb})$ \\
\hline$\Delta \mathrm{q}$ & +0.01 & +0.04 & -0.01 & -0.01 & -0.01 \\
$\Delta \mathrm{V}$ & +3.3 & +5.6 & -2.1 & +0.7 & +0.2 \\
\hline
\end{tabular}

$308 \mathrm{Sb}$ on the electron density laplacian and bonding network of the tetrahedrite is depicted in 309 figure $4 \mathrm{a}$ and $4 \mathrm{~b}$, respectively. Interestingly, as $\mathrm{Se}$ substitutes $\mathrm{Sb}$ a new chemical bond 
310 appears between the selenium atom and the sulphur one of the $2 a$ site in spite of the large

311 interatomic distance (4.027 $\AA$ ); The bond is characterized by a bond path between both atoms 312 and a bond critical point located $c a \cdot \mathrm{x}=24$ (Figure 4a). The Se- $\mathrm{S}_{2 \mathrm{a}}$ interatomic distance is $3131.156 \AA$ shorter than the $\mathrm{Sb}-\mathrm{S}_{2 \mathrm{a}}$ one of the pure tetrahedrite. The appearance of this new bond 314 implies a distortion of the octahedron around the $\mathrm{S}_{2 \mathrm{a}}$ atom; the $\mathrm{Cu}-\mathrm{S}-\mathrm{Cu}$ angle amounts to $315153.07^{\circ}$ and the sulphur atom moves out of the $\mathrm{Cu}_{4}$ plane by $17.9^{\circ}$ in the direction of Se. As 316 to the case of the Te for Sb substitution, the bonding network of the structure is not affected 317 compared to that of the pure tetrahedrite (Figure $4 \mathrm{~b}$ ). Some differences in the atomic charge 318 and volume changes between these two types of substitutions can be observed (Tables 7 and 319 8). First, the atomic charges are barely varying upon Te substitution. By contrast, $\mathrm{S}_{2 \mathrm{a}}$ and $\mathrm{Sb}$ 320 undergo significant increase and decrease, respectively, of their charge upon Se substitution, 321 which can be correlated to the appearance of the new bond between these atoms.

322 The volumes are affected in various ways. For both $\mathrm{Se}$ and Te substitutions, the 323 volume of $\mathrm{S}_{2 \mathrm{a}}$ increases drastically by up to 5 and $7 \mathrm{Bohr}^{3}$, respectively, and that of $\mathrm{Cu}_{12 \mathrm{e}}$ 324 (bonded to $\mathrm{S}_{2 \mathrm{a}}$ ) decreases by $2.5 \mathrm{Bohr}^{3}$, on average. The $\mathrm{Cu}_{12 \mathrm{~d}}$ atoms being far from the 325 substitution site, their volumes are not affected. As to the substituted site $\mathrm{Sb}$, the volume 326 decreases (increases) drastically (slightly) when Se (Te) is the substituting atom, these 327 variations being in line with the differences in atomic sizes between $\mathrm{Sb}$, Se and Te. Since the 328 substitution at the $\mathrm{Sb}$ site is energetically equally plausible by $\mathrm{Se}$ and $\mathrm{Te}$, we can infer that the 329 total contributions to the formation energy of the various structural, electronic and bonding 330 changes occuring in the structures are comparable. 


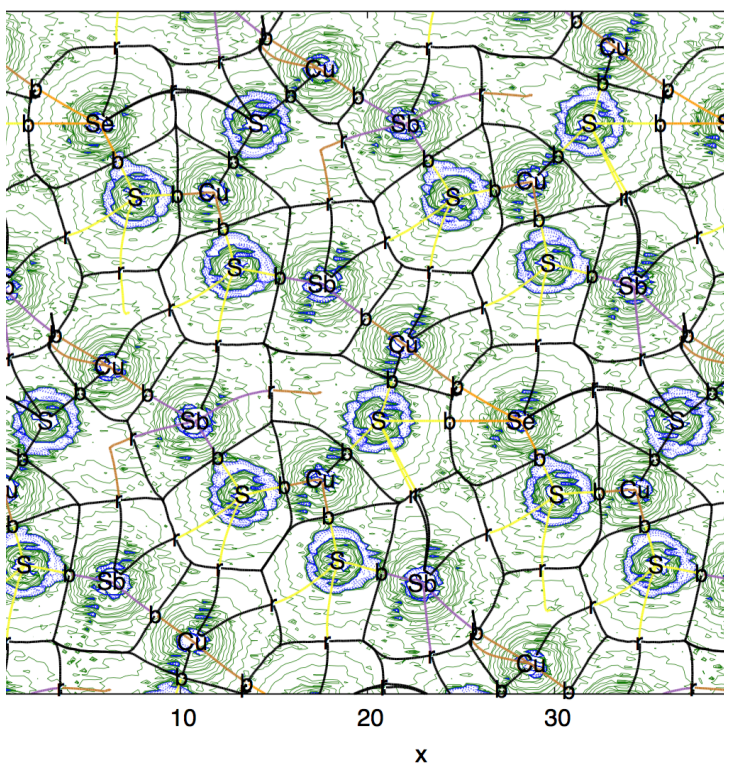

a) Se substitution for $\mathrm{Sb} 8 c$

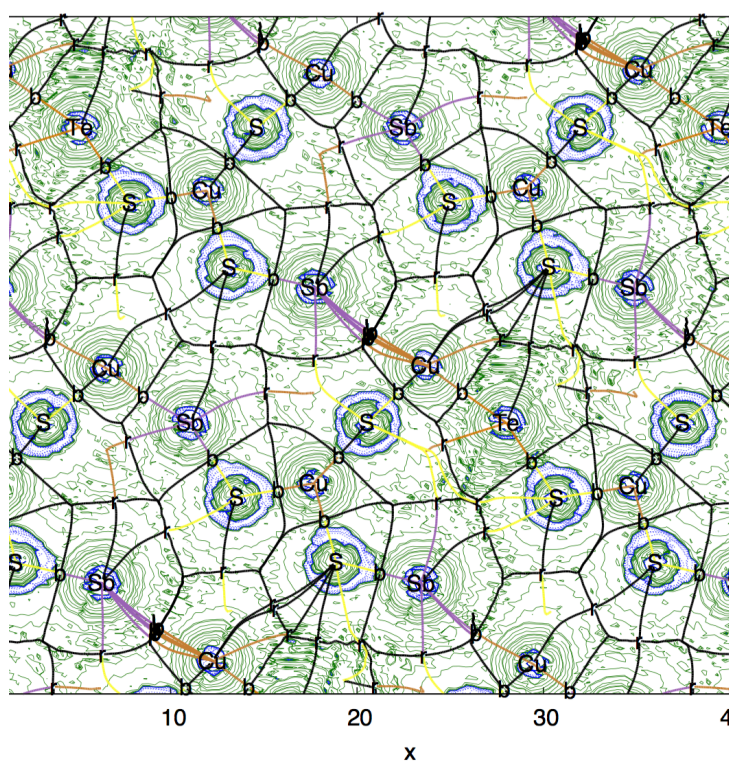

b) Te substitution for $\mathrm{Sb} 8 \mathrm{c}$

335 Fig. 4: Electron density laplacian of substituted tetrahedrite. a) Se substitution for $\mathrm{Sb} 8 c$; b)

336 Te substitution for $\mathrm{Sb} 8 c$. Legend. b: bond critical point; r: ring critical point; c: cage critical

337 point. Color legend: electron accumulation in blue; electron depletion in green.

Table VII: Variation of the atomic charge (in electron charge unit) and atomic sites volume (in bohr ${ }^{3}$ ) upon Se substitution for $\mathrm{Sb} 8 c$.

\begin{tabular}{llllll}
\hline & $24 \mathrm{~g}(\mathrm{~S})$ & $2 \mathrm{a}(\mathrm{S})$ & $12 \mathrm{e}(\mathrm{Cu})$ & $12 \mathrm{~d}(\mathrm{Cu})$ & $8 \mathrm{c}(\mathrm{Sb})$ \\
\hline$\Delta \mathrm{q}$ & +0.03 & +0.05 & -0.01 & 0 & -0.06 \\
$\Delta \mathrm{V}$ & -0.90 & +5.1 & -2.32 & 0 & -4.07 \\
\hline
\end{tabular}


Table VIII: Variation of the atomic charge (in electron charge unit) and atomic sites volume (in bohr ${ }^{3}$ ) upon Te substitution for $\mathrm{Sb} 8 c$.

\begin{tabular}{llllll}
\hline & $24 \mathrm{~g}(\mathrm{~S})$ & $2 \mathrm{a}(\mathrm{S})$ & $12 \mathrm{e}(\mathrm{Cu})$ & $12 \mathrm{~d}(\mathrm{Cu})$ & $8 \mathrm{c}(\mathrm{Sb})$ \\
\hline$\Delta \mathrm{q}$ & +0.01 & +0.01 & 0 & +0.01 & -0.02 \\
$\Delta \mathrm{V}$ & +0.60 & +7.2 & -2.7 & -0.2 & +0.6 \\
\hline
\end{tabular}

Partial conclusions. Irrespective of both the substituting and the substituted atoms, 346 the atomic charge changes are quite weak on all sites, the maximum being 0.06 electron 347 charge unit. When substitution occurs on the $\mathrm{S}_{24 \mathrm{~g}}$ site, irrespective of the substituting atom, 348 charge change is only noticeable on the $\mathrm{S}_{2 \mathrm{a}}$ site. When substitution occurs on the $\mathrm{Sb}_{8 \mathrm{c}}$ site, the largest charge change occurs on this site while being weaker as Te substitutes for $\mathrm{Sb}$. of the site $\mathrm{Cu}_{12 \mathrm{e}}$, which is adjacent to the site $\mathrm{S}_{2 \mathrm{a}}$, decreases, though to a lesser extent. As one could expect, the impact of the substitution on the local volume changes is weaker when the 354 site of interest is far from the substituted one (e.g. volume of the $\mathrm{Cu}_{12 \mathrm{~d}}$ site when the replacement is on the $\mathrm{Sb}$ site). modifications when Te substitutes for $\mathrm{S}_{24 \mathrm{~g}}$ or $\mathrm{Sb}$, respectively. In the case of $\mathrm{Se}$, bigger structural distortions have been evidenced with the breaking of a $\mathrm{Cu}_{12 \mathrm{e}}-\mathrm{Sb}$ bond when the substitution occurs on $\mathrm{S}_{24 \mathrm{~g}}$ site and the formation of a Se-S $\mathrm{S}_{2 \mathrm{a}}$ one when the substitution occurs on $\mathrm{Sb}$ site. 
SUBSTITUTED TETRAHEDRITE: EXPERIMENTAL PART

DFT calculations of formation energies and total volume changes showed that : i) the most favourable situation corresponds to a single atom substitution, ii) selenium is preferred

366 for the sulphur substitution whereas tellurium and selenium are equally likely to replace

367 antimony, whereas QTAIM calculations evidenced larger structural and chemical distortions 368 when Se is the substituting element irrespective of the substituted site. Since these results 369 seem inconsistent, we experimentally investigated the following compositions: $370 \mathrm{Cu}_{12} \mathrm{Sb}_{3.5} \mathrm{Se}_{0.5} \mathrm{~S}_{13}, \mathrm{Cu}_{12} \mathrm{Sb}_{4} \mathrm{~S}_{12.5} \mathrm{Te}_{0.5}$ and $\mathrm{Cu}_{12} \mathrm{Sb}_{3.5} \mathrm{Se}_{0.5} \mathrm{~S}_{12.5} \mathrm{Te}_{0.5}$. We have not investigated $371 \mathrm{Cu}_{12} \mathrm{Sb}_{3.5} \mathrm{Te}_{0.5} \mathrm{~S}_{13}$ and $\mathrm{Cu}_{12} \mathrm{Sb}_{4} \mathrm{~S}_{12.5} \mathrm{Se}_{0.5}$ as these works were already done by Bouyrie et al. ${ }^{45}$ 372 and $\mathrm{Lu}$ et $\mathrm{al.} .^{44}$, respectively, and the authors found single-phased materials with a tetrahedrite 373 structure.

\section{Synthesis and characterization}

The three aforementioned ternary and quaternary alloys have been prepared by mixing

377 their constitutive elements with high purity grade in required proportion in evacuated $\left(\sim 10^{-}\right.$ $378{ }^{2} \mathrm{~Pa}$ ) sealed silica ampoules. The mixture was heated up to $680{ }^{\circ} \mathrm{C}$ and maintained at this temperature for $8 \mathrm{~h}$. In order to get the equilibrium state, the samples have been quenched from melt in cold water and annealed at $400^{\circ} \mathrm{C}$ for about $150 \mathrm{~h}$. The constitutive phases of the samples were evidenced by X-ray powder diffraction using a Bruker D8 Advance

382 diffractometer with $\mathrm{Cu}-\mathrm{K}$ radiation in the $2 \theta$ range from $5^{\circ}$ to $80^{\circ}$ and their proportion were 383 evaluated by Rietveld refinement. 
Results

The X-ray diffraction patterns for the three investigated samples are given in Figure 5 and the constitution of the alloys with the percentage of each phase determined by Rietveld

391 refinement are given in Table 9.

When one Te atom is substituted for a S one, the alloy is constituted of one phase only

393 which crystallizes in a tetrahedrite structure. As expected the lattice parameter of this phase (a $394=1036.1 \mathrm{pm})$ is larger than that of the pure sulphur tetrahedrite ( $\mathrm{a}=1032.4 \mathrm{pm}$, see above). 395 When one Se atom is substituted for a $\mathrm{Sb}$ one, the alloy is constituted of two phases in an 396 equivalent ratio. One of these phases crystallizes in a tetrahedrite structure with a lattice 397 parameter $\mathrm{a}=1034.3 \mathrm{pm}$, the other one crystallizes in a famatinite structure with the lattice 398 parameters $\mathrm{a}=539.0 \mathrm{pm}$ and $\mathrm{c}=1076.1 \mathrm{pm}$ which are larger than those of the pure sulphur 399 famatinite ( $\mathrm{a}=538.5 \mathrm{pm}$ and $\mathrm{c}=1075.4 \mathrm{pm}$, see above). When one Se atom is substituted for a $400 \mathrm{Sb}$ one and one Te is substituted for a $\mathrm{S}$ one, the alloy is mainly constituted (95\%) of a 401 tetrahedrite phase, the secondary phase (5\%) crystallizing in a famatinite structure.

402 The whole results show that in spite of low formation energies and high volume 403 changes, alloys containing a tellurium atom at a sulphur site stabilize the tetrahedrite 404 structure. This statement is in agreement with the QTAIM calculations, which find lower 405 structural and chemical distortions when Te is the substituting element. 


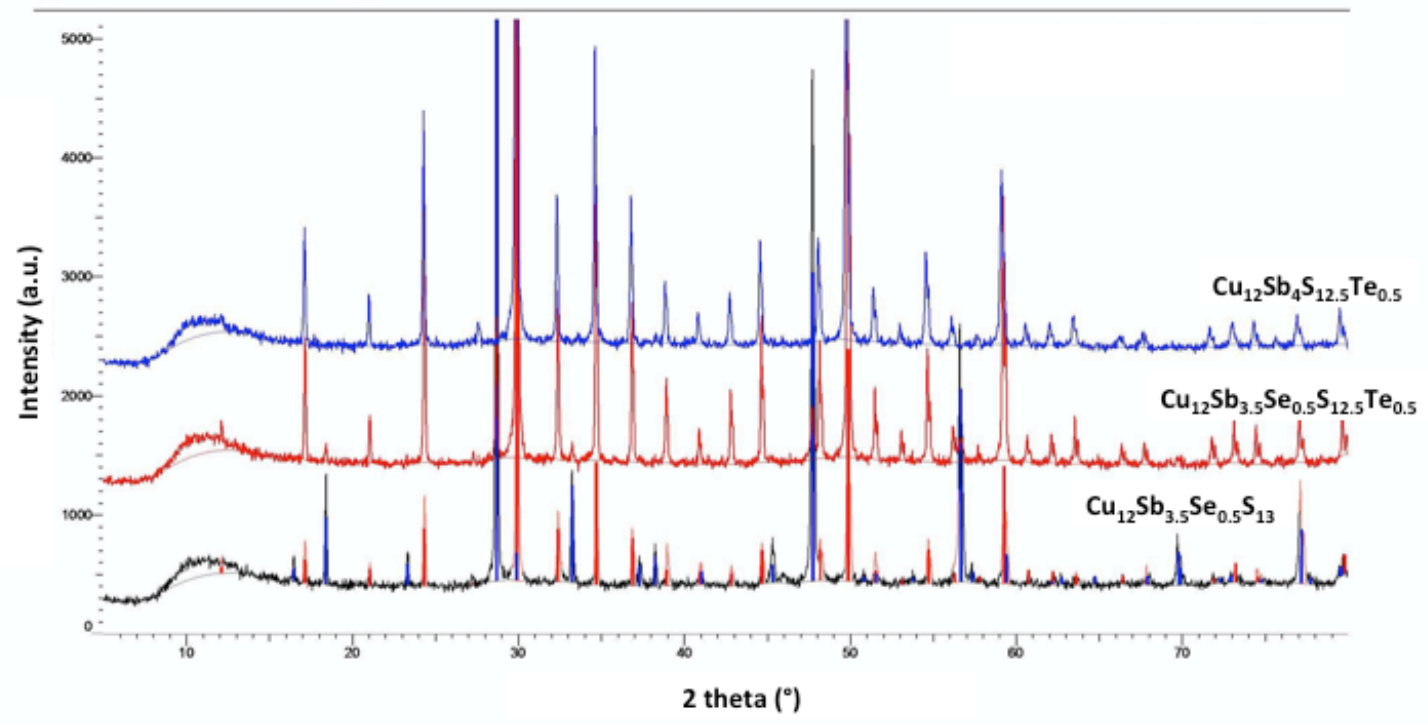

406

407 Fig. 5: X-ray diffraction patterns of $\mathrm{Cu}_{12} \mathrm{Sb}_{4} \mathrm{~S}_{12.5} \mathrm{Te}_{0.5}, \mathrm{Cu}_{12} \mathrm{Sb}_{3.5} \mathrm{Se}_{0.5} \mathrm{~S}_{13}$ and $408 \quad \mathrm{Cu}_{12} \mathrm{Sb}_{3.5} \mathrm{Se}_{0.5} \mathrm{~S}_{12.5} \mathrm{Te}_{0.5}$ alloys

409

Table IX: Constitution of the $\mathrm{Cu}_{12} \mathrm{Sb}_{4} \mathrm{~S}_{12.5} \mathrm{Te}_{0.5}, \quad \mathrm{Cu}_{12} \mathrm{Sb}_{3.5} \mathrm{Se}_{0.5} \mathrm{~S}_{13}$ and $\mathrm{Cu}_{12} \mathrm{Sb}_{3.5} \mathrm{Se}_{0.5} \mathrm{~S}_{12.5} \mathrm{Te}_{0.5}$ samples and percentage of each phase determined by $\mathrm{X}$-Ray diffraction measurements and Rietveld refinement.

Sample composition $\quad$ Sample constitution (\%)

Tetraedrite Famatinite

$\mathrm{Cu}_{12} \mathrm{Sb}_{4} \mathrm{~S}_{12.5} \mathrm{Te}_{0.5}$

0

$\mathrm{Cu}_{12} \mathrm{Sb}_{3.5} \mathrm{Se}_{0.5} \mathrm{~S}_{13}$

45

55

$\mathrm{Cu}_{12} \mathrm{Sb}_{3.5} \mathrm{Se}_{0.5} \mathrm{~S}_{12.5} \mathrm{Te}_{0.5}$

95

5

\section{CONCLUSION}

In this work, we investigated Se and Te substitutions in tetrahedrite by coupling DFT

413 and QTAIM calculations. DFT calculations of formation energies and total volume changes

414 showed that the most favourable situation corresponds to a single atom substitution and that 
415 selenium is preferred for the sulphur substitution whereas tellurium and selenium are equally

416 likely to replace antimony. By contrast, QTAIM calculations evidenced irrespective of the

417 substituted site, larger structural and chemical distortions when Se is the substituting element.

418 In order to clarify these inconsistencies, we experimentally investigated three alloys and

419 found that by contrast to a Se substitution for $\mathrm{Sb}$, a Te susbtitution for $\mathrm{S}$ stabilizes the

420 tetrahedrite structure. This investigation shows that a DFT calculation of formation energies

421 and total volume changes is not sufficient to put forward conclusions on alloys stability. By

422 giving chemical and structural information on a compound, in addition of being a good

423 method to explain the structure-properties relationships, QTAIM appears as a valuable

424 method to get information on phase stabilities.

425

426 ACKNOWLEDGEMENTS

427 This work is financially supported by China Scholarship Council (CSC N²01608530165).

428 This work was granted access to the HPC resources of the Centre Informatique National de

429 l'Enseignement Supérieur (CINES), Montpellier, France under allocation A0050806881 made

430 by the Grand Equipement National de Calcul Intensif (GENCI). It was also granted access to 431 the HPC resources of Aix-Marseille Université financed by the project Equip@Meso (ANR432 10-EQPX-29-01) of the program "Investissements d'Avenir" supervised by the Agence 433 Nationale de la Recherche.

434

435 REFERENCES

436 1. E. H. Roseboom, An investigation of the system $\mathrm{Cu}-\mathrm{S}$ and some natural copper 437 sulfides between $25^{\circ}$ and $700{ }^{\circ} \mathrm{C}$, Econ. Geol. 61, 641-672 (1966).

438 2. P.B. Barton, The Fe-Sb-S system, Econ. Geol. 66, 121-132 (1971). 
439 3. B. J. Skinner, F. D. Luce, E. Makovicky, Studies of the sulfosalts of copper III.Phases 440 and phase relations in the system Cu-Sb-S, Econ. Geol. 67, 924-938 (1972).

441 4. P.B. Barton Jr., Solid solutions in system $\mathrm{Cu}-\mathrm{Fe}-\mathrm{S}$. Part I: The $\mathrm{Cu}-\mathrm{S}$ and $\mathrm{CuFe}-\mathrm{S}$ joins, $442 \quad$ Econ. Geol. 68, 455-465 (1973).

443 5. M. E. Fleet, Phase Equilibria at High Temperatures, Rev. Mineral. Geochem. 61, 365$444 \quad 419(2006)$.

445 6. F. Tesfaye Firdu, P. Taskinen, Thermodynamics and Phase Equilibria in the (Ni, Cu, 446 $\mathrm{Zn})-(\mathrm{As}, \mathrm{Sb}, \mathrm{Bi})-\mathrm{S}$ Systems at Elevated Temperatures $\left(300-900^{\circ} \mathrm{C}\right)$, Aalto University 447 Publications in Materials Science and Engineering (2010).

448 7. S. Maske, B.J. Skinner, Studies of the sulfosalts of copper: I, Phases and phase 449 relations in the system Cu-As-S, Econ. Geol. 66, 901-918 (1971).

450 8]. R.W. Potter, An electrochemical investigation of the system copper-sulfur, Econ. 451 Geol. 72, 1524-142 (1977).

452 9. R.P. Elliot, Constitution of Binary Alloys 1st supplement, McGraw-Hill. New York $453 \quad$ (1965).

454 10. M. Hansen, K. Anderko, Constitution of binary alloys. McGraw-Hill (1965).

455 11. T.B. Massalski, $\mathrm{Cu}-\mathrm{Sb}$ (copper-antimony). In: Binary alloy phase diagrams, vol 2, 456 2nd edn. The Materials Information Society, Materials Park (1990).

457 12. V.F. Ross, The formation of intermediate sulfide phases in the solid state, Econ. Geol. 458 49, 734-752 (1954).

459 13. J.H. Wernick, K.E. Benson, New semiconducting ternary compounds, J. Phys. Chem. 460 Solids 3, 157-159 (1957).

461 14. L. Cambi, M. Elli, Processi Idrotermali-sintesi di solfosali da ossidi di metalli e metalloidi 2 Cuprosolfoantimoniti, Chimica \&Industria 47, 136-147 (1965). 
463 15. R.A. Kuliev, A.N. Krestovnikov, V.M. Glazov, Phase Equilibrium and Intermolecular Interactions in Systems Formed by Copper and Antimony Chalcogenides, Russ. J. Phys. Chem. (Engl. Transl.) 43, 1721-1723 (1969).

16. R.A. Kuliev, A.N. Krestovnikov, V.M. Glazov, Phase equilibria between copper and antimony chalcogenides, Izvest Akad Nauk Sssr Neorg Materialy 5, 2217-2218 (1969).

17. A.A. Godovikov, Bismuth Sulfosalts : their chemical composition, synthesis and classification. In Pecularities of the chemical composition, synthesis, classification, Nauka, Moscow, Russia (1972).

18. N.A. Il'yasheva, Investigation of the system $\mathrm{Cu}_{2} \mathrm{~S}_{-} \mathrm{Sb}_{2} \mathrm{~S}_{3}$ at $320-40{ }^{\circ} \mathrm{C}$, Neorg. Mater. 9, 1677-1679 (1973).

19. L.T. Bryndzia, A. M. Davis, Liquidus phase relations on the quasi-binary join $\mathrm{Cu}_{2} \mathrm{~S}-$ $\mathrm{Sb}_{2} \mathrm{~S}_{3}$ : Implications for the formation of tetrahedrite and skinnerite, Amer. Mineral. 74, 236-242 (1989).

20. M.I. Golovei, V.I. Tkachenko, M.Yu. Rigan, N.P. Stasyuk,Phase diagram of the system $\mathrm{Cu}_{2} \mathrm{~S}_{-} \mathrm{Sb}_{2} \mathrm{~S}_{3}$ in the region of existence of $\mathrm{CuSbS}_{2}$ ", Neorg. Mater. 26, 48-50

21. S. Karup-Møller, E. Makovicky, Skinnerite $\mathrm{Cu}_{3} \mathrm{SbS}_{3}$, a new sulfosalt from the 480 IIimaussaq alkaline intrusion, South Greenland, Amer. Mineral 59, 889-895 (1974).

22. H. J. Whitfield, Polymorphism in skinnerite $\mathrm{Cu}_{3} \mathrm{SbS}_{3}$, Solid State Commun. 33, 747482 748 (1980).

483 23. A. Pfitzner, Disorder of $\mathrm{Cu}^{+}$in $\mathrm{Cu}_{3} \mathrm{SbS}_{3}$ :structural investigations of the high- and lowtemperature modification, Z. Kristallogr. 213, 228-236 (1998).

24. L. Pauling, E.W. Neuman, The crystal structure of binnite, $(\mathrm{Cu}, \mathrm{Fe})_{12} \mathrm{As}_{4} \mathrm{~S}_{13}$, and the chemical composition and structure of minerals of the tetrahedrite group, $Z$. Kristallogr. 88, 54-62 (1934). 
25. K. Tatsuka, N. Morimoto, Tetrahedrite stability relations in the Cu-Sb-S system, Econ. Geol. 72, 258-270 (1977).

26. Y.A. Chang, J.P. Neumann, U.V. Choudary, Phase Diagrams and Thermodynamic Properties of Ternary Copper-Sulfur-Metal Systems, Incra Monograph VII, The Metallurgy of Copper (1979).

493

27. E. Makovicky, B.J. Skinner, Studies of the sulfosalts of copper VII. Crystal structures of the exsolution products $\mathrm{Cu}_{12.3} \mathrm{Sb}_{4} \mathrm{~S}_{13}$ and $\mathrm{Cu}_{13.8} \mathrm{Sb}_{4} \mathrm{~S}_{13}$ of unsubstituted synthetic tetrahedrite, Can. Mineral. 17, 619-634 (1979).

28. N.A. Il'yasheva, Peculiarities of tetrahedrite crystallization in the system $\mathrm{Cu}-\mathrm{Sb}-\mathrm{S}$, Neorg. Mater. 20, 563-657 (1984).

29. T.-T. Chen, Compositional and thermal study on natural and synthetic phases in the system $\mathrm{Ag}_{2} \mathrm{~S}-\mathrm{Cu}_{2} \mathrm{~S}-\mathrm{Sb}_{2} \mathrm{~S}_{3}-\mathrm{Bi}_{2} \mathrm{~S}_{3}$, Degree of doctor, Cornell University (1971)

30. J. Garin, E. Parthé, The crystal structure of $\mathrm{Cu}_{3} \mathrm{PSe}_{4}$ and other ternary normal tetrahedral structure compounds with composition 13564, Acta Cryst. B 28, 3672-3674 (1972).

503 31. A. Kyono, M. Kimata, Crystal structures of chalcostibite $\left(\mathrm{CuSbS}_{2}\right)$ and emplectite $\left(\mathrm{CuBiS}_{2}\right)$ : Structural relationship of stereochemical activity between chalcostibite and emplectite, Am. Mineral. 90, 162-165 (2005).

32. B. J. Wuensch, The crystal structure of tetrahedrite, $\mathrm{Cu}_{12} \mathrm{Sb}_{4} \mathrm{~S}_{13}$, Z. Kristallogr. 119, $437-453$ (1964).

508 33. T. Balic Zunic, E. Makovicky, Determination of the crystal sructures of $\mathrm{TiPbSbS}_{3}$, 509 $(\mathrm{Ti}, \mathrm{K}) \mathrm{Fe}_{3}\left(\mathrm{SO}_{4}\right)_{2}(\mathrm{OH})_{6}$ and $\mathrm{Cu}_{3} \mathrm{SbS}_{3}$ from X-ray powder diffraction data, Mat. Sci. Forum 166-169, 659-664 (1994). 
511 34. M. Babanly, Y. Yusibov, N. Babanly, The EMF Method with Solid State Electrolyte in the Thermodynamic Investigation of Ternary Copper and Silver Chalcogenides, Electromotive Force and Measurement in Several Systems, Publisher InTech (2011).

514 35. P. Hohenberg; W. Kohn, Inhomogeneous electron gas, Phys. Rev. 136, B864-B871 515 (1964).

516 36. W. Kohn, L.J. Sham, Self-Consistent Equations Including Exchange and Correlation Effects, Phys. Rev. 140, A1133-A1138 (1965).

518 37. J.P. Perdew, K. Burke, M. Ernzerhof, Generalized Gradient Approximation Made Simple, Phys. Rev. Lett. 77, 3865-3868 (1996).

$520 \quad 38 . \quad$ P. E. Blöchl, Phys. Rev. B 50, 17953 (1994).

521 39. P. Giannozzi, S. Baroni, N. Bonini, et al., Quantum Espresso : a modular and open522 source software project for quantum simulations of materials, J. Phys.: Condens. Matter 21, 395502 (2009).

524 40. R.F.W. Bader, Atoms in Molecules - A Quantum Theory, Oxford University Press, 525 Oxford, (1990).

526 41. A. Otero-de-la-Roza, E. R. Johnson, V. Luaña, Comput. Phys. Commun. 185, 10071018 (2014).

42. W. Lai, Y. Wang, D.T. Morelli, X. Lu, Adv. Funct. Mater. 25, 3648-3657 (2015).

529 43. X. Lu, D.T. Morelli, Y. Xia, F. Zhou, V. Ozolins, H. Chi, X. Zhou, C. Uher, High SEPpPerformance Thermoelectricity in Earth-Abundant Compounds Based on Natural

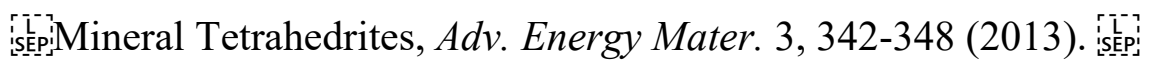

532 44. X. Lu, D. T. Morelli, Y.Wang, W. Lai, Y. Xia, V. Ozolins, Phase Stability, Crystal 533 Structure, and Thermoelectric Properties of $\mathrm{Cu}_{12} \mathrm{Sb}_{4} \mathrm{~S}_{13-\mathrm{x}} \mathrm{Se}_{\mathrm{x}}$ Solid Solutions, Chem. Mater. 28, 1781-1786 (2016). 
535 45. Y. Bouyrie, C. Candolfi, V. Ohorodniichuk, B. Malaman, A. Dauscher, J. Tobola, B. Lenoir, Crystal structure, electronic band structure and high-temperature thermoelectric properties of Te-substituted tetrahedrites $\mathrm{Cu}_{12} \mathrm{Sb}_{4-\mathrm{x}} \mathrm{Te}_{\mathrm{x}} \mathrm{S}_{13}(0.5 \leq \mathrm{x} \leq 2.0)$, J. Mater. Chem. C 3, 10476-10487 (2015).

539 